\title{
A comparison of coupled microeconomic and mental health devastating alterations between low-income and affluent countries afflicted with COVID-19
}

\author{
Xinxin Chu \\ Department of Economics, The University of Sheffield, Sheffield, UK \\ E-mail: achuxinxin@163.com
}

Received 6 February 2021

Accepted 7 June 2021

\begin{abstract}
.
BACKGROUND: The exponential increase in the rate of individuals' affliction by SARS-CoV-2 (COVID-19) has put extreme strains on health care systems worldwide and has sparked fears of an impending economic recession and mental turmoil.

OBJECTIVE: The review discusses the impact of COVID-19 on medical crises in two sections, focusing on the evidence presented from both neuropathological and epidemiological perspectives. First, this paper outlines how countries have implemented containment and appraises its effect on the microeconomy. Second, it highlights how government support for the economic crisis caused by COVID-19 depends on the size of a country's economy. Third, it attempts to explain how COVID19 has affected business by explicitly evaluating each industry divided into primary, secondary, and tertiary sectors. Finally, we assert an extended discussion on the challenges and post-pandemic outlook.

METHODS: Peer-reviewed studies from inception until 2021 were searched in the Google scholar, PubMed, and Scopus databases.

RESULTS: Through the imposition of restrictions and lockdown measures to contain the COVID-19 pandemic spread, besides arising a broad array of mental health concerns, a drastic drop in liquidity and significant spillover effect across almost all the global economic system has ensued.

CONCLUSION: The COVID-19 implication on socioeconomic issues and mental wellbeing, as the most devastating sequelae of the current pandemic, is of great importance to curb the infection and deprive post-pandemic sequelae, demanding prompt actions.
\end{abstract}

Keywords: COVID-19, mental health, psychosocial distress, economic crisis, socioeconomic impact, coronavirus, economic sectors

\section{Introduction}

The ongoing upsurge of coronavirus disease 2019 (COVID-19) achieved pandemic status on March 11,2020 . The infected individuals with severe acute respiratory syndrome coronavirus 2 (SARS-CoV-2) have extended to over 141 million globally, leading to 3,047,159 deaths as of April 2021. COVID-19 establishes a hostile environment [1] paving the way for fundamental shifts in the life condition, which entails 
applying to a new optimized living with a monumental ripple effect on human life's psychosocial and financial aspects, particularly in the workplace [2]. Governments around the world have implemented concrete restriction measures in an endeavor to stem the exponential COVID-19 breakout. These measures include border shutdowns, social distancing, travel restrictions, and quarantine. These measures, particularly in high and upper-middle-income nations with impactful economies, spark caveats of propensity to a financial downturn [3]. Scientists declare that the pandemic's industrial damage is put into context by considering the unprecedented increase in sector liabilities in the post-Napoleonic, and World War times. In line with this, the U.S. Labor Department asserted that over 26 million individuals have filed for unemployment insurance (U.I.) in just the first month of the pandemic [4].

Besides economic devastations, we address COVID-19 implications in exacerbating mental health incurred in two rather distinct ways. Firstly, upon direct viral infection's neuropathological effects compounding physiologic, mental wellbeing. Secondly, we approach the more general psychological effects of COVID-19-related stressors on the pandemic-afflicted society, such as unemployment, economic strains, housing overcrowdings, and hurdles in accessing social support networks, which are likely to accentuate the mental distress burden [5]. Indeed, these stressors tune-up mental turmoil rates and reduce psychosocial and physical health associated with public grounds, which further provokes emotional problems. Among the public, COVID19 contagious panic has prompted psychological patterns such as depression, confusion, stress, and anxiety. The abrupt closure of municipal services and the trades falling flat have also played a detrimental role in individuals' mental health alteration with direct percussion on workforce productivity. Notably, a broad spectrum of COVID-associated traits are in intimate association with mental disorders, explicitly parenting, revenue losses because of the pandemic, and suffering a preexisting illness, and increased vulnerability [6].

Collectively, the prevalence of mental distress in juveniles after abating strict pandemic measures sustains intensely elevated, over twofold higher than the before COVID-19 era, demonstrating the importance of this issue as a post-pandemic sequela COVID-19 to be addressed. Thus, upon controlling viral transmission, morbidities, and financial strains due to epidemic [7], we must understand the
COVID-19 pandemic's coupled psychosocial and economic implications concerning the underlying causes of each category to facilitate the implementation of effective compensatory measures. Herein, mental health alterations concerning the neuropathological and psychosocial impacts of COVID-19 have been briefly addressed. Furthermore, a review of the SARS-CoV-2's deleterious consequences on economic systems concerning different economic sectors will be comprehensively discussed.

\section{Part one - Pandemic-associated mental health ramifications}

\section{Perceived SARS-CoV-2 implications in brain ensuing associated neurological symptoms}

Emerging bodies of thought implicate COVID-19 as a primary culprit in the central nervous system (CNS), providing fertile ground for aberrant mental behaviors to flourish [8]. The neurological implication of COVID-19 is further supported by a broad array of clinical manifestations that potentially indicates neurological involvement [9] in COVID-19 patients, as well as the fact that anosmia and ageusia are present in more than two-thirds of patients. Thus, it implies the profound CNS virulence of COVID19. Strikingly, research claims that the preponderance of neurological symptoms, such as alterations in orientation and awareness and cerebrovascular disease (CVA), rise concomitantly with the disease's burden. A cohort of 58 COVID-19 afflicted individuals recently demonstrated that encephalopathy and acute respiratory distress syndrome (ARDS) are robustly associated, especially with signs of agitation, corticospinal tract damage, and confusion [10].

\subsection{Speculative modulatory impact of COVID-19 on the hypothalamus may influence the brain neurophysiology}

Multiple avenues of research in post-mortem human brain tissue have witnessed signs of COVID19 there, including the hypothalamus. Noteworthy, prominent predisposing indexes for the severity of COVID-19 (male gender, senescence, obesity, hypertension, diabetes) [11] are strongly modulated by physiologic or pathologic conditions of the hypothalamic circuits that play a pivotal role in maintaining the homeostasis. Hypothalamic-pituitary-adrenal 


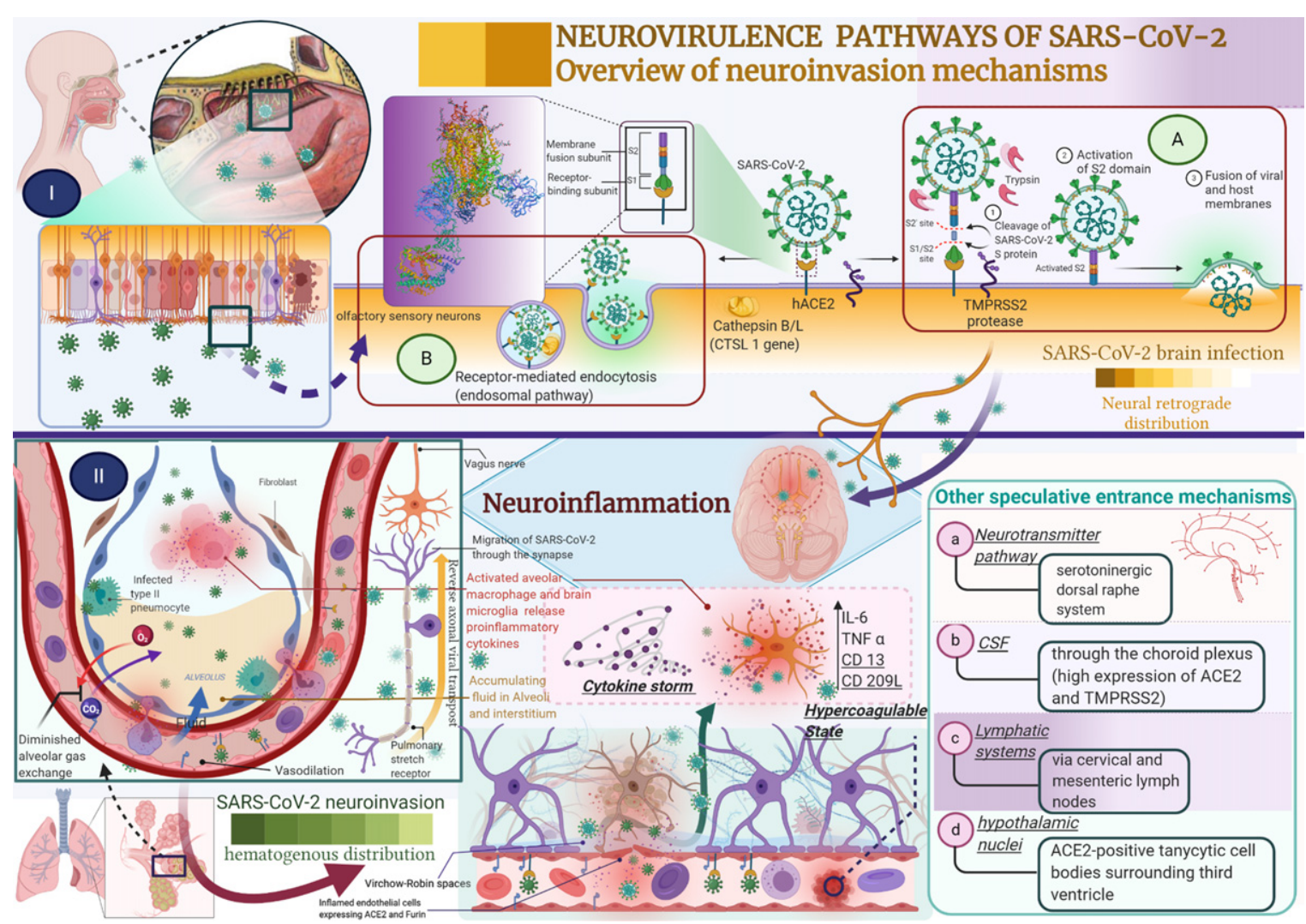

Fig. 1. Neurovirulence pathways of SARS-CoV-2 (COVID-19). (I) Coronavirus could invade the nasal sustentacular epithelium and olfactory sensory neurons, reaching the brain through the olfactory bulb. Invasion incurs by binding the SARS-CoV-2 spike to its receptor, ACEII, with either the membrane fusion pathway (A) or the receptor-mediated endocytosis (B). (II) Vascular damage due to the inflammatory response against the high load of coronavirus in the lung may also contribute to further distributing the virus by the bloodstream or by the reverse axonal viral transport from pulmonary sensory neurons. Regardless of the entry mechanisms, once the SARS-CoV-2 infiltrates the brain, a vast inflammatory response and cytokine storm occurs, leading to neural damage. Other speculative pathways for viral particles to enter the brain are also shown.

axis (HPA) alteration due to COVID-19 infection may consequently lead to metabolic disturbances that influence brain function (Fig. 1) [12] and neuroendocrine dysregulation, which could potentially contribute to significant depression. Interestingly, a portion of severe depression in patients is intimately associated with dysfunctional HPA activity in the brain, which its anti-depressive potency has revealed in rodent studies [13]. Thus, acute COVID19 brain infection exerts profound mood alteration symptoms such as pronounced mental distress and anxiety.

\section{The impact of mental health alterations on the burden of COVID-19}

The pandemic's psychical influence among COVID-19 inpatients is a global health concern. The mental status of these patients is affected by multiple distinct factors, including strict quarantine after a positive diagnosis, stigma, protracted hospitalization, and insufficient support network [14]. An independent study in the USA assessed the psychiatric conditions in extended intervals of the epidemic in about 69 million people, including over 62,000 SARS$\mathrm{CoV}-2$ patients. This study showed robustness in the association between mental distress and COVID-19; once the positive viral test is established, approximately $20 \%$ of COVID-19 patients face a psychotic disorder in the next three months. Likewise, investigations in Italy on 402 COVID-19 inpatient cases who could survive, during their first four weeks after discharge, unveiled the distinct prevalence of anxiety, depression, and post-traumatic stress symptoms (PTSS) among SARS-CoV-2 afflicted people compared to otherwise healthy controls (all $p<0.001$ ) [15]. Also, a high proportion of adults surviving 
COVID-19 self-rated in a broad spectrum of mental distresses such as PTSS (28\%), depression (31\%), insomnia (40\%), anxiety (42\%), and obsessivecompulsive (O.C.) symptoms (20\%). Collectively, $56 \%$ were assessed in the psychopathological range in one clinical aspect or more. Drastically, patients with preexisting psychiatric illnesses have a $65 \%$ increased risk of a positive diagnosis with COVID19 , even accounting for other predisposing elements [16]. Of note, although the scientists witnessed no apparent newly diagnosed mental conditions, such as schizophrenia in COVID-19 patients, the enormously increased risk of relapse in individuals with preexisting psychotic disorders garnered their attention.

\subsection{Key comorbidities and predisposing factors of mental disorders concerning the COVID-19 pandemic}

Morbidity, low sociodemographic standards, and psychological issues are significant contributing factors to prominently higher susceptibility to depressive states. For instance, the depression's prevalence in individuals with chronic obstructive pulmonary disease (COPD) is estimated to be $27 \%$; type 2 diabetes, $20 \%$ [17]; myocardial infarction, $20 \%$; cancer, $13 \%$ to $17 \%$ [18] and stroke, $29 \%$ to $33 \%$ [19]. Multiple epidemiological studies have confirmed various preexisting diseases contributing to the COVID19 infection intensity and mortality (Table 1) [20]. In this context, the overwhelming body of evidence indicates that compared to the general public, depression and anxiety are more common between individuals afflicted with chronic morbidities during the pandemic [21]. To shed light on this, Meurs et al., by implementing epidemiological assessments, evaluated over ninety thousand cases. Their data analysis demonstrated a robust eighty percent increase in the susceptibility to anxiousness and depressive symptoms in people with diabetes. Furthermore, hypertension is deemed a significant risk factor contributing to higher susceptibility to infection. Also, senescence is perceived as a critical determiner of higher intensity and danger in COVID-19 afflicted individuals. Consistently, estimates in Japan declare that between SARS-CoV-2 afflicted individuals aged 70-79 and more than 80 years, the mortality scores were $6.8 \%$ and $14.8 \%$, respectively. In contrast, the mortality rate in all age categories was assessed at $2.6 \%$ as of May 2020 [22].

\subsection{SARS-CoV-2 and psychological sequelae: Epidemiological findings on the convergence of viral infections and non-transmitting psychosocial conditions}

The World Health Organization (WHO) addresses the purport of mental health as the condition of wellbeing to the extent that individuals vigorously exploit their potentialities to circumvent everyday life stress load and workplace competencies. Investigations imply that influential economic crises or natural disasters usually incur depressive symptoms, anxiousness, drug abuse, PTSS, and a rise in suicidal ideation [23]. In the same fashion, upon the COVID-19 pandemic, mental wellbeing and psychological conditions have become vital health concerns. In this context, multiple avenues of research have cemented that social distancing, isolation, social and economic strains, and deceptive news are the key players leading to a spectrum of negative psychological responses [24]. These factors are related to the occurrence, intensity, and progression of a psychiatric condition, such as severe depressive symptoms, anxiousness, frustrations, and suicidal ideation.

Remarkably, the overwhelming body of evidence asserted that young adults, students, women, and individuals with a preexisting psychiatric disorder are profoundly prone to heighten mental health disorders [25]. In agreement with the latter statement, a prestigious meta-analysis regarding women's mental health during the pandemic unveiled increased levels of depressive symptoms (27\%) in women suffering partner's sexual harassment through the lockdowns (Table 2) [26]. Although data reveals children and adolescents have lower susceptibility to infection from SARS-CoV-2, their mental wellbeing has been hindered through the epidemic. Concrete lockdown measures, school shutdowns, deficits in physical exercises, abnormal eating syles, dysregulated resting routines, parental violence, and child abuse have culminated in stress, lack of patience and concentration, monotony, and psychiatric disorders in them [27], demonstrating the significant mental strain during the pandemic that prompts researchers to shed new light on this issue.

\subsubsection{Underscoring the detrimental inequities in the prevalence of psychological disorders before and during the pandemic}

Before the pandemic, researchers had appraised the prevalence of depressive symptoms to be less than $5 \%$ in public. Also, assessments showed that 
Table 1

Epidemiological documents debating on the relation of the risk factors and comorbidities and COVID-19

\begin{tabular}{|c|c|c|c|c|c|}
\hline Study & Design & Number and population & Outcome & Comorbidity/risk factor & Notes \\
\hline Matsuzawa, Japan [79] & Retrospective cohort study & $\begin{array}{l}151 \text { adult patients ( }>18 \text { years) } \\
\text { mean age } 60 \pm 19 \text { years }\end{array}$ & $\begin{array}{l}\text { (I) In-hospital death, ECMO, } \\
\text { ICU admission } \\
\text { (II) Mental confusion, } \\
\text { SBP } \leq 90 \mathrm{mmHg}\end{array}$ & $\begin{array}{l}\text { HTN }(25 \%) \\
\text { D.M. }(20 \%)\end{array}$ & $\begin{array}{l}\text { Mental confusion in HTN }(15.1 \%) \\
\text { and non HTN patients }(7.3 \%) \text {. } \\
\text { ACEIs/ARBs prevent confusion in } \\
\text { COVID-19 patients with HTN }\end{array}$ \\
\hline Yang, China [80] & $\begin{array}{l}\text { Electronic health record } \\
\text { network (UK Biobank) } \\
\text { cohort study }\end{array}$ & $\begin{array}{l}421014 \text { UK Biobank } \\
\text { participants, mean age } \\
67.80 \text { years }\end{array}$ & COVID-19 & $\begin{array}{l}\text { Pre-pandemic diagnosed } \\
\text { psychiatric disorders }(12 \%)\end{array}$ & $\begin{array}{l}\text { COVID-19 occurrence in } 0.87 \% \text { of } \\
\text { cases with a diagnosed psychiatric } \\
\text { disorder and } 0.41 \% \text { in other } \\
\text { patients }\end{array}$ \\
\hline Jia, UK [81] & Cross-sectional online survey & $\begin{array}{l}\mathrm{N}=3097 \text { adults, } 84 \% \text { female } \\
\text { mean age } 44 \text { years }\end{array}$ & $\begin{array}{l}\text { Depression, anxiety, and } \\
\text { stress scores }\end{array}$ & $\begin{array}{l}\text { Risk factors contributing to } \\
\text { the enhanced propensity of } \\
\text { COVID-19 }\end{array}$ & $\begin{array}{l}\text { Mean scores for depressive } \\
\text { symptoms ( } 7.69) \text {, stress }(6.48) \text {, and } \\
\text { anxiousness }(6.48) \text { markedly } \\
\text { surpassed regular public rates }\end{array}$ \\
\hline Savage, UK [82] & $\begin{array}{l}\text { Prospective longitudinal } \\
\text { cohort study }\end{array}$ & $\begin{array}{l}214 \text { students, } \\
\text { females }=72.0 \%, \text { mean } \\
\text { age }=20.0 \text { years }\end{array}$ & $\begin{array}{l}\text { Psychological health (A), } \\
\text { physical wellbeing (B), } \\
\text { stress (C), and sedentary } \\
\text { behavior (D) }\end{array}$ & $\begin{array}{l}\text { Self-reported mental health } \\
\text { issue } 30 \%\end{array}$ & $\begin{array}{l}\text { Decrease in } \mathrm{A}(\mathrm{F}(2.2,465.0)=6.6) \\
\mathrm{B}(\mathrm{F}(2.7,591.0)=4.8) . \text { Increase in } \\
\mathrm{C}((\mathrm{F}(2.5,536.2)=94.0), \mathrm{D}(\mathrm{F} \\
(2.7,578.9)=41.2)\end{array}$ \\
\hline Alessi, Brazil [83] & Cross-sectional study & $\begin{array}{l}\mathrm{N}=120, \text { mean age } \\
54.8 \pm 14.4 \text { years }\end{array}$ & $\begin{array}{l}\text { Minor psychiatric disorders, } \\
\text { diabetes related emotional } \\
\text { distress, sleep disorders }\end{array}$ & D.M. I and D.M. II & $\begin{array}{l}\text { Psychological distress, } 44.2 \% \text {. } \\
\text { diabetes-related emotional distress, } \\
29.2 \% \text { and sleep disorders, } 77.5 \%\end{array}$ \\
\hline Zheng, China [84] & Retrospective cohort study & $\begin{array}{l}66 \text { patients, mean age } 47 \\
\text { years }\end{array}$ & $\begin{array}{l}\text { Progression to severe } \\
\text { COVID-19 }\end{array}$ & $\begin{array}{l}\text { Metabolic-associated fatty } \\
\text { liver disease } 68 \%\end{array}$ & $\begin{array}{l}\text { Obesity was confirmed as a } \\
\text { contributing factor to COVID-19 } \\
(p=0.03)\end{array}$ \\
\hline Iob, UK [85] & Community cohort study & $\begin{array}{c}\mathrm{N}=51417 \text { participants, mean } \\
\text { age, } 48.8,51.1 \% \text { female }\end{array}$ & Depressive symptoms & $\begin{array}{l}\text { Low SEP, preexisting } \\
\text { physical and psychological } \\
\text { disorders, psychological or } \\
\text { physical abuse, and } \\
\text { insufficient community } \\
\text { support }\end{array}$ & $\begin{array}{c}\text { Low SEP (OR, 5.22)/low community } \\
\text { network }(\mathrm{OR}, 12.72) / \text { experiences } \\
\text { of physical or psychological abuse } \\
(\mathrm{OR}, 13.16) / \text { past psychologic } \\
\text { disease }(\mathrm{OR}, 12.99)(\text { all } p<0.001)\end{array}$ \\
\hline
\end{tabular}

ACEI: angiotensin-converting enzyme inhibitor, ARBs: Angiotensin II receptor blockers, D.M.: diabetes mellitus, ECMO: extracorporeal membrane oxygenation, HTN: hypertension, OR: odds ratio, SEP: socioeconomic position. 
Table 2

Epidemiological evaluation of the prevalence of psychological conditions in countries with highest confirmed cases as of December 2020

\begin{tabular}{|c|c|c|c|c|c|}
\hline Study/reference & Region & $\begin{array}{l}\text { Evaluation } \\
\text { method(s) }\end{array}$ & Population & $\begin{array}{l}\text { Prevalence of mental } \\
\text { health disorders }\end{array}$ & Notes \\
\hline Ettman et al. [86] & USA & PHQ-9 & $\begin{array}{l}\mathrm{N}=1441 \text { during the } \\
\text { pandemic and } \\
\mathrm{N}=5065 \\
\text { pre-pandemic }\end{array}$ & $\begin{array}{l}\text { Depression-moderately } \\
\text { severe: } 7.9 \% \\
\text { Depression-severe: } 5.1 \%\end{array}$ & $\begin{array}{l}\text { The depressive symptom was } \\
\text { up to } 3 \text {-fold greater upon } \\
\text { the outbreak rather than } \\
\text { earlier periods }\end{array}$ \\
\hline Roy et al. [87] & India & N.A & $\begin{array}{l}\mathrm{N}=662 \text { adults }(>18 \\
\text { years })\end{array}$ & $\begin{array}{l}\text { Anxiety-72\% } \\
\text { Sleep disturbance- } 12 \%\end{array}$ & - \\
\hline Zhang et al. [88] & Brazil & CPDI & 638 adult & $\begin{array}{l}\text { Mild to moderate } \\
\text { distress-52\% } \\
\text { Severe distress- } 18.8 \%\end{array}$ & $\begin{array}{l}\text { Lower-income and higher } \\
\text { rates of exposure to risk } \\
\text { factors concomitantly } \\
\text { increase the depressive } \\
\text { symptoms }\end{array}$ \\
\hline Karpenko et al. [89] & Russia & HADS & $\mathrm{N}=352$ & $\begin{array}{l}\text { Anxiety-29.83\% } \\
\text { Depression- } 16.76 \%\end{array}$ & $\begin{array}{l}\text { The risk of financial problems } \\
\text { and the wellbeing of old } \\
\text { adults or relatives afflicted } \\
\text { with comorbidities are the } \\
\text { leading causes of distress }\end{array}$ \\
\hline Essadek et al. [90] & France & $\begin{array}{l}\text { IESR/PHQ- } \\
\text { 9/GAD-7 }\end{array}$ & $\begin{array}{l}\mathrm{N}=8004(\text { mean } \\
\text { age }=21.7 \text { years })\end{array}$ & $\begin{array}{l}\text { Depression- } 43 \% \\
\text { Anxiety-39.19 } \\
\text { Distress-42.94\% }\end{array}$ & $\begin{array}{l}\text { Female sex, urban life, } \\
\text { exposure to } \\
\text { COVID+patients, and } \\
\text { previous psychiatric illness } \\
\text { or chronic disease were } \\
\text { associated with higher } \\
\text { depression scores }\end{array}$ \\
\hline Özdin et al. [91] & Turkey & HADS/HAI & $\begin{array}{l}\mathrm{N}=343 \text { adults aged } \\
18 \text { or older }\end{array}$ & $\begin{array}{l}\text { Depression-23.6\% } \\
\text { Anxiety-45.1\% }\end{array}$ & $\begin{array}{l}\text { Female sex, urban life, and } \\
\text { past mental condition were } \\
\text { informed to contribute to } \\
\text { more significant } \\
\text { anxiousness }\end{array}$ \\
\hline Jia et al. [81] & UK & $\begin{array}{l}\text { PSS-4 } \\
\text { GAD-7 } \\
\text { PHQ-9 }\end{array}$ & $\begin{array}{l}\mathrm{N}=3097 \text { adults } \\
\text { aged } \geq 18 \text { years }\end{array}$ & $\begin{array}{l}\text { Mean scores for } \\
\text { depression }(7.69 \text {, } \\
\text { stress-6.59/anxiety- } \\
6.48\end{array}$ & - \\
\hline Rossi et al. [92] & Italy & $\begin{array}{l}\text { GPS-PTSS/ } \\
\text { PSS PHQ-9/ } \\
\text { GAD-7/ISI }\end{array}$ & $\begin{array}{l}\mathrm{N}=18147(79.6 \% \\
\text { women })\end{array}$ & $\begin{array}{l}\text { PTSS-37.14\% } \\
\text { Severe depression-17.3\% } \\
\text { Severe anxiety-20.8\% } \\
\text { Severe insomnia-7.3\% }\end{array}$ & - \\
\hline
\end{tabular}

CPDI: COVID-19 Peritraumatic Distress Index, GAD-7: generalized anxiety disorder 7, GPS-PTSS: Global Psychotrauma Screen-posttraumatic stress symptoms subscale, HADS: Hospital Anxiety and Depression Scale, HAI: Health Anxiety Inventory, IES-R: Impact of Event Scale-Revised, ISI: Insomnia Severity Index, PHQ: Patient Health Questionnaire for Depression and Anxiety, PSS: Perceived Stress Scale.

the depression rate was dramatically two-fold higher among individuals with lower socioeconomic positions (SEP). Early in the pandemic quarantine, mental health deteriorated, and mental distress prominently accelerated (the 19\% prevalence, from 2017 to 2019 , increased to 30\% in April 2020), with higher levels in young adults and females. Interestingly, several studies declared that pandemic contributes to the further widening of preexisting mental health inequities [28]. It is igniting to assess the previous documents concerning background alterations in psychiatric wellbeing. To get the ball rolling, the Adult Psychiatric Morbidity Survey (APMS) in 2014 deciphered that individuals in the age group of 16 to $64(17 \%$ to $18 \%)$ were approximately two times more prone to show clinical manifestations of common mental disorders (CMD) than individuals older than sixty-five years old $(10 \% \quad 65-74,8 \% 75<)$. In 1993, women with ages ranging from 16 to 24 (19.2\%) were assessed two times more susceptible than men of the same group age $(8.5 \%)$ to show CMD characteristics. Upon 2014 the gap rose approximately threefold (9.1\% among men and $26 \%$ among women). Research in the UK demonstrates that the prevalence of individuals experiencing CMD rose from 23.3\% in 2017 to 2019 to $36.8 \%$ in April 2020. Still, the increase was 8.6 percent more substantial amid 18 to 34 compared to 50 to 64-year-old individuals [29]. Altogether, age and gender were the main contributing factors determining the public's 
psychiatric health before COVID-19. The gap in CMD scores among young women and men and different ages has dramatically increased during the outbreak [30].

\subsection{The COVID-19 quarantine measures' repercussion on physical wellbeing concerning mental health state}

Lockdown measures have undermined mental and physical wellbeing. Controversially, upon the outbreak, relative distress and sedentary behavior exponentially accelerated due partly to the lesser competence of remote working and distance learning [31]. The WHO suggested that those in isolation should engage in regular physical activities to avert the mental health crisis matters since having physical activity on a daily schedule promisingly reduces the susceptibility to depression in young adults. However, research assumes that the strict lockdown measures impede an individual's potentiality to get strolling outdoors, contributing to a significant decrease in practical exercising sessions and a pronounced rise in sedentary behavior [32]. Collectively, compelling data leverages the significance of deploying indoor exercises in alleviating psychiatric distress during the pandemic.

Overall, it is noteworthy that multiple factors discussed in sections 2 and 3 are inextricably interconnected and are converged in many dimensions to paint a worrying picture in terms of the potential pandemic's effect on mental health. Of note, mental turmoil associated with the economic crisis will collude in detrimental socioeconomic effects as described in the following sections.

\section{Major contributing factors towards insidious social implication of COVID-19}

In a similar fashion to the SARS and MERS pandemics, COVID-19 has vastly been implicated in challenging the daily life routines in the community and workplace, influencing many aspects of society. Imposed lockdown measures affected social and entertainment events and led to total disarrange or delay of nationwide championship events and tournaments, disturbance of the commemoration of customs, religious, and carnival occasions, the shutdown of holy places, movie theatres, sports clubs, and gymnasiums [33]. Hence, lockdowns due, in part, to increased remote working and online education profoundly harmed community resources which reinforce public health and the community in the workplace because face-to-face engagements play a substantial role in many eastern societies. It is noteworthy that a higher number of committed crimes, including vandalism, break-ins, and a rise in online fraud, incur upon protraction of these closures [34].

Dramatically, WHO, in Nov. 2020, declared that more than two-thirds of nations reported reduced access to psychological care for high-risk groups. Howsoever, multiple avenues of research have documented the widespread experience of pandemicrelated psychological distresses such as unemployment, shifting to remote working, altered workplace environment, bereavement in the death of relatives, and persistent worries regarding psychiatric and physical wellbeing, which leads to an increased demand for social supports [35]. Notwithstanding the COVID-19 crisis's effect on the general population, these concerns are more significant among susceptible people, including individuals contracted with insidious harassment or insufficiently strong support network and SEP, and individuals with previously confirmed psychiatric or physical morbidities. Consecutively, mentioned social groups are hardest hit in the aftermath of the depleted psychiatric health care resources [36].

\section{Part two - Economic percussions}

\section{COVID-19-associated economic shock}

The increasing number of quarantine days, fiscal policies, and global travel ban profoundly have hit the global economy. Noteworthy, the crucial levels of liquidity are associated with the sharp drop in the worldwide stock exchange that significantly compounded the market's volatility [37].

To explain the negative industrial impact of the outbreak, David Miles, former Chief UK Economist at Morgan Stanley, declares that the current economic scene is put into context by considering such leadership pays out to the Napoleonic and World War times in which the financial liabilities faced exponential rise [38].

To circumvent these implications, central banks globally have intervened by fiscal and monetary policies to maintain liquidity and cushion the economic shock. Notwithstanding, the financial sequela's extent broadly varies; particularly, certain public sectors are perceived to be more vulnerable. Thus they 
will require excessive endeavors to replenish their depleted sources to the pre-crisis level [39].

\subsection{Compulsory "shelter-in-place” measures' impact in the economic context}

Emphasizing the pandemic's devastating economic impact, the Brookings Institution, by modeling quarantine in different states and the entire U.S., estimated an average weekly expense of 140 USD for each student. Thus, New York City's whole month quarantine could bring about $\$ 1.1$ bn expenses; also, a complete quarantine of the U.S. for three months will be equal to one percent of GDP. In line with that, research in the UK assessed that prolonged lockdown measures would expend three percent of GDP [40]. On the contrary, Wren-Lewis claims that the outbreak influence will be short-lived according to the defined underlying source and expected endpoint instead of an actual economic recession [41].

Strikingly, an overwhelming body of evidence surmises semantic second-round effects, for instance, vast supply chain impacts (such as a nosedive decline in requirement of supplement and raw material businesses by the COVID-hit companies) and the significant deceleration in order, will increase unemployment, particularly in markets not in the first line of lockdowns' hit [42].

\subsection{Evaluation of COVID-19 impacts on microeconomy regarding workforce mental health}

Small and medium-sized enterprises (SMEs), workers' productive capacity, and families' income are differently ramified by SARS-CoV-2 across industries and firms [43]. To some extent, it is a subject of predisposition to China, the dominant source of feedstock for most SMEs, and exposure to the global supply chain. Some sectors may also hit harder; for example, daily wage jobs such as street food vendors remain disgracefully unsanitary. Due to probable unhealthy preparation conditions, these small businesses are robustly hit [44].

Although hygiene and food production industries face a pronounced boost in demand, most SMEs that are the lifeblood of employment growth are obligated to dampen services [45]. Consequently, these small and local industries, including the prevailing workforce in impoverished nations, are profoundly at the risk of bankruptcy and vast staff unemployment. Consistently, a considerable portion of workers around the world have been unemployed or put on furlough. This will concomitantly cumulate huge deficits such as people's difficulties in paying rent, mortgages, and multiple household expenditures resulting in laborforce mental distress. On the other hand, fear of facing another financial crisis has put strains on banks in low-income countries (LIC). High street banks demand at least $45 \%$ deposits to approve a retail banking service [46].

Of note, the financial strain of coping with the pre-pandemic and current demands, economic uncertainty, constriction of opportunities, and job insecurity are accompanied by a drop in self-esteem and establish an environment hostile for psychiatric disorders like depression, alcohol abuse, and suicide in many economic sectors workplaces affected by the pandemic hardships [42]. Indeed, psychological diseases are one of the most common causes of lost workdays. Depression, anxiety disorders, and suicide are robustly associated with adversities in life such as unemployment or even short-time furlough in the case of underprivileged employees.

\subsection{Disparities in COVID-19 effects on the socioeconomic state between affluent and low-income countries}

Compelling data analyses in different countries claim that the COVID-19 socioeconomic crisis's social policies may increase inequality, discrimination, and widespread unemployment [47, 48]. Interestingly, the widespread business closures without sufficient financial protection plans, particularly in LIC, increase economic hardships, incurring increased job losses and preponderance of underprivileged individuals [49]. To shed light on this, the World Bank data analysts assessed that over 11 million individuals would slip into extreme deprivation across the Pacific and East Asia during the pandemic. In line with that, the pandemic's effect on national GDP and poverty rates was elegantly analyzed by researchers claiming that 49 million people in LIC and lower-middle-income (LMIC) nations would fall deeper into poverty in 2020 (living on less than $\$ 1.90$ per day). Additionally, research assumes that the worldwide supply chain disturbances and the sharp drop in commodity costs push these nations toward debt restructuring [50].

To further clarify the disparity of the economic impact, a study in the USA witnessed that the lowest income-earning individuals have a relative consumption loss of $18.3 \%$. In comparison, for the highest 
income quantile, the loss is only 5.9\%. Moreover, the average recovery time from COVID-19 in the lowest income quantile is one year and two months, while it takes approximately seven months for the highest income-earning individuals to replenish their deprivement during the pandemic [51].

In the case of health care system inequalities, research assumes that in most African nations, the proportion of doctors to the general population is $2 / 10,000$. In contrast, Italy, one of the healthiest countries worldwide, has 41 medical doctors per 10,000, which indicates the vulnerability of health care in low-income countries [52]. It is noteworthy that there are publicly-funded care, social assistance beneficiaries, and exemptions in most affluent countries. Some estimates indicate that up to $65 \%$ of health care in LIC, such as most African nations, is made from outof-pocket expenses. Strikingly, during the outbreak, interruptions in in-person services have led countries $(70 \%)$ to adopt teletherapy and telemedicine to compensate for the gaps in health care services. The deployment varies significantly from more than $80 \%$ to less than $50 \%$ among HIC and LIC, respectively [53].

Besides, WHO surveys demonstrated that less than $20 \%$ of nations could sufficiently pay the expenses for mental wellbeing support services. Notwithstanding, $90 \%$ of nations have asserted to cover psychological care services in their main pandemic control strategies [54], implying the influence of the financial state of countries in their response to the pandemic.

Transforming sector-scale liabilities into poverty involvement at a local level interprets the outbreak's microeconomic impacts effectively. However, investigating this would have gone beyond the scope of this paper.

\subsubsection{Social protection plans and benefits maintain the viability of the microeconomy}

As of December 2020, 215 governments have stated schemes or launched 1,414 social protection measures (Table 3). Nations have implemented social protection measures like cash transfers, unemployment benefits, food or vouchers, and waiving financial obligations (e.g., rents) to alleviate the crisis's consequences. Interestingly, social assistance serves as $62 \%$ of global responses, with cash-based transfers appearing $34 \%$ of measures. Of note, food support plans and school feeding projects feature prominently. Drastically, when taking into account all social assistance, coverage would involve an estimated 1.283 billion individuals [55].
To get the ball rolling, assessments in the U.S. suggests that the concomitant unemployment insurance (U.I.) and the Coronavirus Aid, Relief, and Economic Security Act (CARES Act) could decrease the replenishment efforts' duration in people suffering significant revenue deprivement from averagely a year to 6.8 months and markedly impede the poverty rise [51].

The Corona Response Investment Initiative launched by the European Union (E.U.) provides short- and extended-term loans to circumvent insufficient liquidity and help employers and self-employed individuals eligible for loans, tax relief, and cash grants. In many high-income countries, governments act as a "buyer of last resort" by paying firms and employers to retain workers to keep firms afloat [56].

Contrary to the affluent nations outlined above, structural differences in economic systems across low and LMIC countries preclude the deployment of pronounced social assistance plans. Noteworthy, the content and implementation of public aid plans alter due to nations' GDP and location [57]. To shed light on this, public aid expenditure varies from $\$ 1.71$ billion to $\$ 515.33$ billion in LIC and HIC, respectively. Indeed, surveys indicate that families from at least 594 million children in poor and LMIC nations received no child and family-associated financial beneficiaries and pensions from their governments to cope with the outbreak [58].

\subsection{Assessment of COVID-19 ramifications on business sectors}

Upon the imposition of lockdown measures, a broad spectrum of impacted sectors reflects the drastic implication of the outbreak on business perturbation [39]. Indeed, the sector's construction and compliance with shifting to remote working are the principal contributing factors that influence the fraction of affected individuals. Drastically, remote working imperatively brings up excessive mental distress to adapt to employees' routines besides workrelated stresses. It is noteworthy that in the U.S., remote working is applicable for approximately $40 \%$ of jobs, and this rate is much lower in most LIC, implying the raised fear and mental distress of contagion in the workplace community [59].

Herein, the COVID-19 implication on different sectors with a brief discussion on mental health impact is discussed. 
Table 3

Evaluation of the social assistance expenses and costs on GDP in countries with highest case-fertility ratio as of December 2020

\begin{tabular}{|c|c|c|c|c|c|c|c|c|}
\hline Country & $\begin{array}{l}\text { Case- } \\
\text { fatality } \\
\text { ratio }\end{array}$ & $\begin{array}{l}\text { Total } \\
\text { cases }\end{array}$ & $\begin{array}{c}\text { Income } \\
\text { level }\end{array}$ & $\begin{array}{l}\text { GDPpc } \\
\text { (local } \\
\text { currency) }\end{array}$ & $\begin{array}{l}\text { Total S.A. } \\
\text { spending } \\
\text { (US\$) }\end{array}$ & $\begin{array}{l}\text { Planned } \\
\text { benefic- } \\
\text { iaries } \\
\text { (ind) }\end{array}$ & $\begin{array}{l}\text { COVID-19- } \\
\text { related } \\
\text { costs } \\
(\% \text { GDP }) \\
\end{array}$ & Notes \\
\hline Mexico & $9.3 \%$ & $1,205,229$ & UMIC & 194203.581 & $\$ 81.2 b n$ & $1 \mathrm{M}$ & $1.9 \%$ & $\begin{array}{l}35 \mathrm{bn} \text { pesos funded from ISSSTE to } \\
\text { provide loans from } 20,000 \text { to } 56,000 \\
\text { pesos to help } 670,000 \text { workers }\end{array}$ \\
\hline Iran & $4.8 \%$ & $1,083,023$ & UMIC & 275999742.3 & $\$ 1.7 \mathrm{bn}$ & $25 \mathrm{M}$ & $13 \%$ & $\begin{array}{l}\text { Cash transfers to households (1.3bn } \\
\text { USD); provided loans to } 23 \mathrm{M} \\
\text { households receiving cash subsidies } \\
\text { (500M US\$) }\end{array}$ \\
\hline UK & $3.5 \%$ & $1,771,552$ & HIC & 32675.466 & $£ 192.3 \mathrm{bn}$ & $11 \mathrm{M}$ & $15 \%$ & $\begin{array}{l}\text { The universal credit standard allowance } \\
\text { increases by } 1,000 \text { pounds covering } \\
\text { over } 4 \mathrm{M} \text { households. Individuals with a } \\
\text { positive test receive } £ 130 \text { for their } \\
\text { quarantine period }\end{array}$ \\
\hline Italy & $3.5 \%$ & $1,770,149$ & $\mathrm{HIC}$ & 29335.712 & $\$ 64.6 b n$ & N.A. & $7 \%$ & $\begin{array}{l}\text { The "Cura Italia" fund; a protection plan } \\
\text { of } € 25 \mathrm{bn} \text { - containing } € 13.5 \mathrm{bn} \text { to } \\
\text { help households. The Decreto di } \\
\text { Rilancio, a stimulus package of } \\
€ 55 \mathrm{bn} \text {, extends the one-off } \\
€ 600-1000 \text { bonus to entrepreneurs and } \\
\text { employed individuals }\end{array}$ \\
\hline Indonesia & $3.1 \%$ & 598,933 & LMIC & 60209291.87 & $\$ 6,7 \mathrm{bn}$ & $23 \mathrm{M}$ & $4.4 \%$ & $\begin{array}{l}\text { The PKH program budget reaches IDR } \\
37.4 \text { trillion (US } \$ 2.5 \text { ), covering 10M } \\
\text { beneficiary families (15 percent of the } \\
\text { population). Also, } 9 \mathrm{M} \text { rural people } \\
\text { receive IDR } 600,000 \text { (US\$ 40) }\end{array}$ \\
\hline Colombia & $2.8 \%$ & $1,392,133$ & UMIC & 20875775.36 & $\$ 9.18 b n$ & $28 \mathrm{M}$ & $2.8 \%$ & $\begin{array}{l}\text { A one-off payment of } \$ 108 \text { for } 3 \mathrm{M} \\
\text { workers. Distribution of } 3 \% \text { of the VAT } \\
\text { refund ( } 47 \$ \text { per household) to } 1 \mathrm{M} \\
\text { low-income families. Besides, } 500,000 \\
\text { poor and vulnerable families are aided } \\
\text { with } 120-286 \$ \text { during the quarantine }\end{array}$ \\
\hline Spain & $2.7 \%$ & $1,712,101$ & HIC & 26677.484 & $\$ 39.4 \mathrm{bn}$ & $5 \mathrm{M}$ & $3.8 \%$ & $\begin{array}{l}\text { GMI for around 5M low-income people. } \\
\text { ERTE established } € 25 \mathrm{M} \text { to protect } \\
\text { revenue (wallet cards, wire transfer, } \\
\text { voucher in stores). } € 300 \mathrm{M} \text { to support } \\
\text { social services and basic needs }\end{array}$ \\
\hline Brazil & $2.7 \%$ & $6,728,452$ & UMIC & 34277.642 & $\$ 18.7 b n$ & $83 \mathrm{M}$ & $12 \%$ & $\begin{array}{l}\text { Allocation of } \mathrm{R} \$ 3 \text { bn for the Bolsa } \\
\text { Familia plan covers additional one } \\
\text { million families }(53,229,083 \\
\text { beneficiaries). Cash transfer } \\
\text { (107-210 } \$ \text { ) for single mothers and } \\
\text { jobless individuals }\end{array}$ \\
\hline USA & $1.9 \%$ & $15,392,194$ & HIC & $62,794.59$ & $\$ 2.3$ trillion & $80 \mathrm{M}$ & $23 \%$ & $\begin{array}{l}\text { CARES acts to provide one-time tax } \\
\text { rebates, unemployment benefits, and } \\
\text { food support for underprivileged ones, } \\
\text { loans, and Federal Reserves. Adults } \\
\text { will get } \$ 1,200 \text { each and children } \$ 500 \\
\text { each }\end{array}$ \\
\hline India & $1.5 \%$ & $9,767,371$ & LMIC & 154600.532 & $\$ 163.8 \mathrm{bn}$ & $745 \mathrm{M}$ & $8.9 \%$ & $\begin{array}{l}87 \text { million farmers in Bihar receive US\$ } \\
26.50 \text { for three months. Uttar Pradesh } \\
\text { state transferred } \$ 82 \mathrm{M} \text { to } 27.3 \mathrm{M} \\
\text { individuals. } 17000 \text { low-income } \\
\text { families in Assam will get } \$ 13 / \text { month }\end{array}$ \\
\hline
\end{tabular}

CARES: Coronavirus Aid, Relief, and Economic Security Act, ERTE: Temporary Employment Adjustment Schemes, GDP: gross domestic production, GDPpc: gross domestic production, GMI: guaranteed minimum income, ind: individuals, ISSSTE: Institute for Social Security and Services for State Workers, PKH: Program Keluarga Harapan, GMI: Guaranteed Minimum Income, S.A.: social assistance, USD: United States dollar. 


\subsubsection{Primary sectors}

5.4.1.1. Agriculture: The agriculture sector's strength is appraised through the pandemic. Investigations reveal that agricultural products' cost has fallen by $20 \%$ due to global sabotage in demand chiefly from accommodation and recreation sectors like hotels and restaurants [60].

Findings explain that food markets are further perturbed by floor trading cessation due primarily to the altered potency of retail trade. As a result, pronounced implications in the market of perishable foods including meat, dairy, and fruits ensue, deepening concerns about many individuals, particularly in developing countries, being pushed under poverty and malnutrition. Conjointly, lockdown measures disturb agricultural goods' outflow channels, decelerate essential production inputs, hinders production cycles, and ultimately dampens production capacity. Interestingly, panic buying is also a substantial culprit in complicating deficits beyond supermarket shelves. In line with that, research claims that panic buying has culminated in increasing $£ 1 b n$ worth of food in UK homes [61].

On the other hand, from a psychosocial view, a recent survey conducted in UK's rural community disclosed that almost $80 \%$ of younger farmers complain of mental distress as their current major insidious problem. Consistently, UK Research and Innovation (UKRI) organization is planning extensive studies on the pandemic's psychiatric effects on farmers to develop a concrete support plan for farmers' communities in crises [62].

5.4.1.2. Petroleum and oil: While considering the oil market outlook concerns, the International Energy Agency has estimated that the transport fuel demand would be the hardest hit sector. The oil demand is mainly due to the industry's consumption and transportation sector, vastly disrupted during the pandemic. Hence, low demand and storage restrictions are liable to have an ongoing depressive effect [63]. To clarify, Saudi, regarded as the Petroleum Exporting Countries (OPEC) Organization leader, boosted its oil provision by $25 \%$, with unprecedented production volumes (from 9.7 million barrels per day dropped to 12.3 million). Consequently, the shock brought about the sharpest single-day nosedive decline in price within the past thirty years, leading to a $24 \%$ decline in Brent Crude from \$34/barrel to $\$ 25.70$ [64].
The pandemic mental health concerns in the oil and gas sector are vital because most field engineers could not shift to remote work and remained in an unstable work environment with restricted contacts and teamwork for longer shifts to cope with boosted production plans. Deliberate research on the psychiatric state of oil industries upon pandemic witnessed that having longer rotations and younger age are prominent risk factors. Also, age-adjusted assessments showed a higher prevalence of anxiety disorders in expatriates than local workers. These data help leaderships plan for maintaining productivity while mitigating the pandemic-related workplace stresses [65].

\subsubsection{Secondary sectors}

5.4.2.1. Manufacturing industry: Quarantine profoundly hindered goods production in China and fared a pronounced decrease in consumption, demand, and utilization of commodities and services. Moreover, for a considerable portion of jobs within a manufacturing company, speculatively $25 \%$, distance working is not a practical option. Thus, the supply chain perturbation due to China's vast exposure and inadequate workforce due to lockdown measures are perceived as significant concerns in this sector, disturbing workforce mental wellbeing [66].

Surveys in the UK explored the devastating role of the SARS-CoV-2 outbreak on manufacturing businesses. Interestingly, results show that more than $98 \%$ of respondents have concerns about the outbreak's harmful effect on the manufacturing trade. Additionally, $80 \%$ of participants predicted an abrupt decrease in income during the next six months. Altogether, as the UK is implementing precautionary measures like other nations, and because of the supply chains worldwide interconnection, it is predictable that anxiety disorders may deploy globally [67].

\subsubsection{Tertiary sector}

5.4.3.1. Education: More than 52\% of countries worldwide imparted educational institutions cessation nationally and shifted to remote teaching [68]. UNESCO assessed that almost 900 million learners, $91.3 \%$ of total enrolled learners, have been affected by the educational institutions' closure. Noteworthy, most students could not keep their part-time jobs due to the closure of local businesses. 
These profound alterations in the students' lifestyle and income, concomitant with nationwide limits, are assumed to implicate young adults' psychiatric wellbeing negatively. Drastically, documents demonstrating the substantial (25\%) prevalence of anxiety among Chinese students leverages this point. In line with that, a comprehensive study on 7140 young adult medical students found that $24.6 \%$ of students developed anxious symptoms upon the pandemic's burst [69]. Collectively, the COVID-19 outbreak inevitably impacts the students' educational experience. Howsoever, there is an ongoing debate on the extent of COVID-19 impacts.

\subsubsection{Finance industry: The COVID-19 pan-} demic has challenged the net cash flow and significantly abated revenue growth. The pandemic has negatively impacted the financial markets globally by modulating the risk levels and putting significant strains on investors [70]. Evaluation of the S\&P 500 index, the Dow Jones Industrial Average, and the Nasdaq Composite, which are the three mostfollowed stock market indices in the United States, showed a steep drop before establishing the CARES Act, which helped their indexes to rise by approximately $7.4 \%$. Moreover, U.S. Treasury bond yields were on the decline to $0.67 \%$. Notably, European bond yields also decreased, similar to the European debt crisis. Germany's DAX, the UK's FTSE 100, and the Euro Stoxx 50, which showed a dramatic decline, increased pronouncedly upon E.U. launching the protection plan [71].

Moreover, Asian emerging markets have been the hardest hit in regional categorization, while European emerging markets have faced the lowest. In Asian markets, similar trends of initial abrupt drop followed by a steep increase due to the rescue packages were observed in China's Shanghai Composite, South Korea's KOSPI, Japan's Nikkei, and Hong Kong's Hang Seng [72]. Collectively, the pandemic's negative implication on emerging stock markets has set off gradually.

Intriguingly, official response time and the composition of government benefits are perceived as the most important contributing factors in tapering off the psychiatric wellbeing effects of COVID-19. The UK Helix Resilience survey on finance sector employees declares that COVID-19 has implicated in less productivity and concentration in 52 percent of the staff. The survey disclosed a rise in consumption of junk food (45\%) and alcohol (32\%) and a drop in exercising time (41\%). Also, nearly half of employees contend with the heightened levels of financial uncertainty. Notably, over half of the finance and banking sector staff asserted that their mental wellbeing is supported in the workplace during the pandemic [72].

On the other hand, recruiting information from Australia's most extensive workplace psychiatric status research shows mental wellbeing in the Australian financial and insurance services workforce has the most robust productivity gains of workers in other industries during the pandemic. Interestingly, compared with other sectors and due to high demand to respond to leadership social protection plans and support customers facing financial uncertainty, the financial service labor force ran into the most significant rise in beneficial stress or eustress, a transitory motivator that enhances productivity and accelerates performance. Also, 42 percent of the banking and finance workforce attest that less commuting culminated in better work and life balance as a positive work-related change [70].

\subsubsection{Medical care and the pharmaceutical} industry: The SARS-CoV-2 outbreak has brought about unprecedented challenges for healthcare systems worldwide [73]. Steep medical care expenses, insufficiency of personal protective equipment (PPE), such as facemasks, and shortage of ICU rooms and ventilators are the main contributing factors that undermine the health care sources. Precisely, COVID-19 has put excess strain on hospitals, having reached maximal resources. Thus, governments have attempted to increase ICU beds and hospitals; even in some regions, governments had to create temporary isolation zones [67]. Consistently, the COVID-19 pandemic has strikingly increased the demand for respiratory ventilators. Nonetheless, accumulating evidence shows that even HIC's current supply is insufficient. Estimates in the U.S. appraise that medical management of a pandemic demands 740,000 ventilators, while the total number of ventilators in the U.S. is 165,000 [74].

From a mental wellbeing perspective, pandemic places further psychological stress on physicians and nurses. Generally, higher workloads and lower recovery time are accompanied by adverse mental health. In particular, pandemic-related anxiety about contagion and spreading the infection to their families, adapting to new and often changing procedures, and utilizing PPE, caring for rapidly dying patients exacerbate factors affecting health care workforce mental health. Thus, adverse psychological effects during the pandemic have risen among health care staff, such 
as burnout, compassion fatigue, anxiety, depression, PTSD, moral injury [74]. Taken together, healthcare policymakers are prompted to develop protective measures to support doctors, nurses, and their families during the pandemic.

\subsubsection{Hospitality, tourism, and aviation: Multi-} ple independent studies estimate that the hospitality and travel industry might be the hardest hit, with hourly employees encountering potentially detrimental upheavals. Marriott International (over 174,000 workers) has put thousands of employees on furlough. Specifically, the COVID-19 outbreak significantly perturbated the hospitality sector globally. The hotel sector showed a significant $11.56 \%$ drop in revenue per room in the U.S. at the beginning of March 2020, while in China, occupancy levels slumped $88 \%$ at the beginning of 2020 . The pandemic is also implicated in a marked decline in the European hotel market [75].

The tourism industry is of significant pandemic hits, impacting both travel supply and demand. The World Travel and Tourism Council alerts that over 50 million workers in the international tourism and travel sector are at risk of unemployment. In line with that, most African countries witnessed a 55-80 percent decline in tourism following the COVID-19 pandemic. International Air Transport Association (IATA) asserted that the global market for air travel decreased markedly with a cumulative revenue loss of US\$113bn [76].

Mental health alterations in this sector are often associated with alternate cooperation and teamwork opportunities related to preventive measures. COVID-19 pandemic increased the vulnerabilities in all staff, their relatives, and passengers to exceptionally high psychological stressors due to contact with potentially infected passengers, increased workload, job insecurity, and loss of income.

\section{Challenges and prospects}

As the pandemic continues deteriorating lives globally, policymakers are challenged to address the vulnerabilities the pandemic has exposed in a way that lays a foundation for vigorously resuscitating society. Indeed, the business and civic communities will regulate the speed and inclusivity of the recovery to a more resilient economic outlook. The primary post-pandemic crisis-recovery planning has been to compensate for the unprecedented levels of relief required for keeping individuals and businesses afloat while facing funding shortfalls. Intriguingly, as in the 2008 financial crisis, fast-moving consumer goods (FMCGs) keep flourishing despite pandemic complications and are perceived as the backbone of the economy, offering work, education, and stability. Notably, researchers believe economies that embrace and plan for the accelerating COVID-19 trends such as digitalization and shift to remote work are most likely to withstand market volatility. Besides, diversification of microeconomic activities, such as business service, innovation, research, technology, arts, and tourism, improves local economies' resilience [77].

As well, mental wellbeing has taken a nosedive, declining to its lowest since 2001, prompting to prioritize mental health remotely. Notably, virtual mental healthcare services and telepsychiatry have faced steep demand, particularly in young adults, and it is assumed to keep progressing even in the post-pandemic era. The increasing social burden of psychiatric diseases will inextricably transcend the scope of mental health services globally. Uncomplicated depression, anxiety, substance abuse, and sleep disturbances are of highly prevalent global psychologic conditions and potentially are the leading disorders exacerbated by the COVID-19 crisis. Randomized clinical trials have shown that the best clinically and cost-effective solution is to enhance primary care physicians' knowledge (PCP-First model) or integrate physical and behavioral health services (Collaborative Care Model) in treating these most prevalent conditions [78].

Noteworthy, data disclosed that more than half of the workforce did not use all of their PTO during the pandemic, thus not sufficiently decompressing the burden. It is perceived that applying enough time off and resting will become of essential employee benefits in 2021. Besides, for the workforce affected by the pandemic, plans like granting debt relief and averting spending cuts in services will be helpful to cope with an excess of workplace pressures. Implementing immense screenings of scathing psychological disorders and faring imminently enhances distressed staff's mental health in the long term. On the other perspective, surveys declare that lockdownassociated weight gain has increased mental stress and dropped self-esteem since March 2020; thus, personalizing the proper home workout will continue to be the principal theme of fitness segment growth. Taken together, recovery plans should be targeted and long-term to ascertain equity in income across demographic groups [23]. 


\section{Conclusion}

We discussed the present documents on the involvement of the COVID-19 outbreak and imposed quarantine in psychological distress and summarized their adverse effect in the socioeconomic crisis. Also, we affirmed the COVID-19 neuroinvasion mechanism as a key player for multiple neurological symptoms in COVID-19. Moreover, harmful stress coping techniques and inadequate social support services are evaluated as detrimental factors in COVID-19-related psychosocial-based disorders. Economic disruptions as a pronounced sequela of restrictions are widely addressed as a worldwide crisis. The containment-associated constraints modulate the supply chain and set off global feedstock exchange by a rippling effect. Also, measures dysregulate the microeconomy by promoting unemployment and preventing liquidity distribution. The social protection and social assistance plans for the COVID-19 outbreak provide more comprehensive financial support to households, entrepreneurs, and firms in affluent countries than most low-income nations. Finally, we further highlighted the economic impact by addressing the outbreak-induced changes to specific financial sectors. In conclusion, it seems that COVID-19-associated mental distress and socioeconomic alterations could be addressed as the most devastating sequelae in the current pandemic. The modification of these negative impacts would help us pave the way to overcome the crisis shortly.

\section{Acknowledgments}

The figure has been created with BioRender.com.

\section{Conflict of interest}

The author declares that he has no conflict of interest.

\section{Data availability}

The datasets used and/or analyzed during the current study are available from the corresponding author on reasonable request.

\section{Funding}

The author received no financial support for the research, authorship, and/or publication of this article.

\section{References}

[1] Kaufman KR, Petkova E, Bhui KS, Schulze TG. A global needs assessment in times of a global crisis: world psychiatry response to the COVID-19 pandemic. BJPsych Open. 2020;6(3).

[2] Serafini G, Parmigiani B, Amerio A, Aguglia A, Sher L, Amore M. The psychological impact of COVID-19 on the mental health in the general population. QJM: An International Journal of Medicine. 2020;113(8):531-7.

[3] Jackson JK, Weiss MA, Schwarzenberg AB, Nelson RM. Global economic effects of COVID-19. 2020.

[4] Gallant J, Kroft K, Lange F, Notowidigdo MJ. Temporary Unemployment and Labor Market Dynamics During the COVID-19 Recession. National Bureau of Economic Research; 2020. Report No.: 0898-2937.

[5] Zhu B, Ma S, Xie R, Chevallier J, Wei Y-M. Hilbert spectra and empirical mode decomposition: A multiscale event analysis method to detect the impact of economic crises on the European carbon market. Computational Economics. 2018;52(1):105-21.

[6] Chen H, Zhang G, Fan D, Fang L, Huang L. Nonlinear Lamb Wave Analysis for Microdefect Identification in Mechanical Structural Health Assessment. Measurement. 2020: 108026

[7] Sun S, Lin D, Operario D. Need for a population health approach to understand and address psychosocial consequences of COVID-19. Psychological Trauma: Theory, Research, Practice, and Policy. 2020;12(S1):S25.

[8] Li Z-G, Cheng H, Gu T-Y. Research on dynamic relationship between natural gas consumption and economic growth in China. Structural Change and Economic Dynamics. 2019;49:334-9.

[9] Wen D, Zhang X, Liu X, Lei J. Evaluating the consistency of current mainstream wearable devices in health monitoring: a comparison under free-living conditions. Journal of medical Internet research. 2017;19(3):e68.

[10] Nalleballe K, Onteddu SR, Sharma R, Dandu V, Brown A, Jasti M, et al. Spectrum of neuropsychiatric manifestations in COVID-19. Brain, behavior, and immunity. 2020;88: 71-4.

[11] Liu S, Yu W, Chan FT, Niu B. A variable weight-based hybrid approach for multi-attribute group decision making under interval-valued intuitionistic fuzzy sets. International Journal of Intelligent Systems. 2020.

[12] Lv Q, Liu H, Yang D, Liu H. Effects of urbanization on freight transport carbon emissions in China: Common characteristics and regional disparity. Journal of Cleaner Production. 2019;211:481-9.

[13] Zhu J, Shi Q, Wu P, Sheng Z, Wang X. Complexity analysis of prefabrication contractors' dynamic price competition in mega projects with different competition strategies. Complexity. 2018;2018.

[14] Chen L, Zhang X, Xu X. Health insurance and long-term care services for the disabled elderly in China: Based on CHARLS Data. Risk Management and Healthcare Policy. 2020;13:155

[15] Mazza MG, De Lorenzo R, Conte C, Poletti S, Vai B, Bollettini I, et al. Anxiety and depression in COVID-19 survivors: Role of inflammatory and clinical predictors. Brain, Behavior, and Immunity. 2020;89:594-600.

[16] Zhang X, Wang T, Wang J, Tang G, Zhao L. Pyramid Channel-based Feature Attention Network for image dehazing. Computer Vision and Image Understanding. 2020: 103003. 
[17] Zhao X, Li D, Yang B, Ma C, Zhu Y, Chen H. Feature selection based on improved ant colony optimization for online detection of foreign fiber in cotton. Applied Soft Computing. 2014;24:585-96.

[18] Zhao X, Li D, Yang B, Chen H, Yang X, Yu C, et al. A two-stage feature selection method with its application. Computers \& Electrical Engineering. 2015;47:114-25.

[19] Rahmani A, Saleki K, Javanmehr N, Khodaparast J, Saadat P, Nouri HR. Mesenchymal stem cell-derived extracellular vesicle-based therapies protect against coupled degeneration of the central nervous and vascular systems in stroke. Ageing Research Reviews. 2020:101106.

[20] Zhang X, Wang D, Zhou Z, Ma Y. Robust low-rank tensor recovery with rectification and alignment. IEEE Transactions on Pattern Analysis and Machine Intelligence. 2019.

[21] Zhang X, Fan M, Wang D, Zhou P, Tao D. Top-k feature selection framework using robust $0-1$ integer programming. IEEE Transactions on Neural Networks and Learning Systems. 2020.

[22] Shibata S, Arima H, Asayama K, Hoshide S, Ichihara A, Ishimitsu $\mathrm{T}$, et al. Hypertension and related diseases in the era of COVID-19: a report from the Japanese Society of Hypertension Task Force on COVID-19. Hypertension Research. 2020;43(10):1028-46.

[23] Zhao X, Ye Y, Ma J, Shi P, Chen H. Construction of electric vehicle driving cycle for studying electric vehicle energy consumption and equivalent emissions. Environmental Science and Pollution Research. 2020:1-15.

[24] Xu Y, Chen H, Luo J, Zhang Q, Jiao S, Zhang X. Enhanced Moth-flame optimizer with mutation strategy for global optimization. Information Sciences. 2019;492:181-203.

[25] Chen H, Heidari AA, Chen H, Wang M, Pan Z, Gandomi AH. Multi-population differential evolution-assisted Harris hawks optimization: Framework and case studies. Future Generation Computer Systems. 2020.

[26] Beydoun HA, Beydoun MA, Kaufman JS, Lo B, Zonderman $\mathrm{AB}$. Intimate partner violence against adult women and its association with major depressive disorder, depressive symptoms and postpartum depression: a systematic review and meta-analysis. Social Science \& Medicine. 2012;75(6):959-75.

[27] Chen L, Sivaparthipan C, Rajendiran S. Unprofessional problems and potential healthcare risks in individuals' social media use. Work. 2021(Preprint):1-9.

[28] Wang M, Chen H, Yang B, Zhao X, Hu L, Cai Z, et al. Toward an optimal kernel extreme learning machine using a chaotic moth-flame optimization strategy with applications in medical diagnoses. Neurocomputing. 2017;267: 69-84.

[29] Wang S, Zhao Y, Li J, Lai H, Qiu C, Pan N, et al. Neurostructural correlates of hope: dispositional hope mediates the impact of the SMA gray matter volume on subjective wellbeing in late adolescence. Social Cognitive and Affective Neuroscience. 2020.

[30] Xiong Z, Xiao N, Xu F, Zhang X, Xu Q, Zhang K, et al. An Equivalent Exchange Based Data Forwarding Incentive Scheme for Socially Aware Networks. Journal of Signal Processing Systems. 2020:1-15.

[31] Zhang X, Jiang R, Wang T, Wang J. Recursive Neural Network for Video Deblurring. IEEE Transactions on Circuits and Systems for Video Technology. 2020.

[32] Hall G, Laddu DR, Phillips SA, Lavie C.J., Arena R. A tale of two pandemics: How will COVID-19 and global trends in physical inactivity and sedentary behavior affect one another? Progress in Cardiovascular Diseases. 2020.
[33] He L, Chen Y, Li J. A three-level framework for balancing the tradeoffs among the energy, water, and air-emission implications within the life-cycle shale gas supply chains. Resources, Conservation and Recycling. 2018;133:206-28.

[34] Lv X, McCabe S. Expanding theory of tourists' destination loyalty: The role of sensory impressions. Tourism Management. 2020;77:104026.

[35] Liu L, Li J, Yue F, Yan X, Wang F, Bloszies S, et al. Effects of arbuscular mycorrhizal inoculation and biochar amendment on maize growth, cadmium uptake and soil cadmium speciation in Cd-contaminated soil. Chemosphere. 2018;194:495-503.

[36] Tsai J, Wilson M. COVID-19: a potential public health problem for homeless populations. The Lancet Public Health. 2020;5(4):e186-e7.

[37] Liu L, Liu S. Integrated Production and Distribution Problem of Perishable Products with a Minimum Total Order Weighted Delivery Time. Mathematics. 2020;8(2):146.

[38] Nicola M, Alsafi Z, Sohrabi C, Kerwan A, Al-Jabir A, Iosifidis $\mathrm{C}$, et al. The socioeconomic implications of the coronavirus pandemic (COVID-19): A review. International journal of surgery (London, England). 2020;78:185.

[39] Cortes GM, Forsythe E. The heterogeneous labor market impacts of the COVID-19 pandemic. Available at SSRN 3634715. 2020.

[40] Keogh-Brown MR, Wren-Lewis S, Edmunds WJ, Beutels P, Smith RD. The possible macroeconomic impact on the U.K. of an influenza pandemic. Health Economics. 2010;19(11):1345-60.

[41] Urinov B. International Experience of Improving Corporate Legislation. Архив научных исследований. 2020; 35.

[42] Deb P, Furceri D, Ostry JD, Tawk N. The economic effects of Covid-19 containment measures. 2020.

[43] Wang L, Yang T, Wang B, Lin Q, Zhu S, Li C, et al. RALF1FERONIA complex affects splicing dynamics to modulate stress responses and growth in plants. Science Advances. 2020;6(21):eaaz1622.

[44] Jain D. Effect of COVID-19 on Restaurant Industry-How to Cope With Changing Demand. Effect of COVID-19 on Restaurant Industry-How to Cope With Changing Demand (April 16, 2020). 2020.

[45] Liu J, Yi Y, Wang X. Exploring factors influencing construction waste reduction: A structural equation modeling approach. Journal of Cleaner Production. 2020;276:123185.

[46] Li L, Strahan PE, Zhang S. Banks as lenders of first resort: Evidence from the COVID-19 crisis. The Review of Corporate Finance Studies. 2020;9(3):472-500.

[47] Xu X, Zhang L, Chen L, Liu C. The role of soil N2O emissions in agricultural green total factor productivity: an empirical study from China around 2006 when agricultural tax was abolished. Agriculture. 2020;10(5):150.

[48] Yang Z, Xu P, Wei W, Gao G, Zhou N, Wu G. Influence of the crosswind on the pantograph arcing dynamics. IEEE Transactions on Plasma Science. 2020;48(8):2822-30.

[49] Costa Dias M, Joyce R, Postel-Vinay F, Xu X. The challenges for labour market policy during the Covid-19 pandemic. Fiscal Studies. 2020;41(2):371-82.

[50] Xu X, Chen H-l. Adaptive computational chemotaxis based on field in bacterial foraging optimization. Soft Computing. 2014;18(4):797-807.

[51] Martin A, Markhvida M, Hallegatte S, Walsh B. Socioeconomic impacts of COVID-19 on household consumption and poverty. Economics of Disasters and Climate Change. 2020;4(3):453-79. 
[52] Zhao X, Zhao X, Yu Q, Ye Y, Yu M. Development of a representative urban driving cycle construction methodology for electric vehicles: A case study in Xi'an. Transportation Research Part D: Transport and Environment. 2020;81: 102279 .

[53] Zhu J, Wang X, Wang P, Wu Z, Kim MJ. Integration of BIM and GIS: Geometry from IFC to shapefile using open-source technology. Automation in Construction. 2019;102:105-19.

[54] Zhou X, Snoswell CL, Harding LE, Bambling M, Edirippulige S, Bai X, et al. The role of telehealth in reducing the mental health burden from COVID-19. Telemedicine and e-Health. 2020;26(4):377-9.

[55] Wu C, Wang X, Chen M, Kim MJ. Differential received signal strength based RFID positioning for construction equipment tracking. Advanced Engineering Informatics. 2019;42:100960.

[56] Saez E, Zucman G. Keeping business alive: the government as buyer of last resort. Econfib Research Brief, March. 2020.

[57] Zhang K, Ruben GB, Li X, Li Z, Yu Z, Xia J, et al. A comprehensive assessment framework for quantifying climatic and anthropogenic contributions to streamflow changes: A case study in a typical semi-arid North China basin. Environmental Modelling \& Software. 2020:104704.

[58] Han X, Zhang D, Yan J, Zhao S, Liu J. Process development of flue gas desulphurization wastewater treatment in coal-fired power plants towards Zero Liquid Discharge: Energetic, economic and environmental analyses. Journal of Cleaner Production. 2020:121144.

[59] Feng S, Lu H, Tian P, Xue Y, Lu J, Tang M, et al. Analysis of microplastics in a remote region of the Tibetan Plateau: Implications for natural environmental response to human activities. Science of The Total Environment. 2020: 140087.

[60] Pu M, Zhong Y. Rising concerns over agricultural production as COVID-19 spreads: Lessons from China. Global Food Security. 2020;26:100409.

[61] Liang L, Ren H, Cao R, Hu Y, Qin Z, Li C, et al. The effect of COVID-19 on youth mental health. Psychiatric Quarterly. 2020:1-12.

[62] Chen H, Chen Y, Yang L. Intelligent early structural health prognosis with nonlinear system identification for RFID signal analysis. Computer Communications. 2020.

[63] Huang Z, Zheng H, Guo L, Mo D. Influence of the position of artificial boundary on computation accuracy of conjugated infinite element for a finite length cylindrical shell. Acoustics Australia. 2020;48(2):287-94.

[64] Jian Q. Challenges and policy responses to labor relations under pandemic prevention and control: China's experience in building decent work. «ТРУД И СОЦИАЛЬНЫЕ ОТНОШЕНИЯ» Рецензируемый научный журнал:81.

[65] Singh V, Gu N, Wang X. A theoretical framework of a BIM-based multi-disciplinary collaboration platform. Automation in Construction. 2011;20(2):134-44.

[66] Anderson RM, Heesterbeek H, Klinkenberg D, Hollingsworth TD. How will country-based mitigation measures influence the course of the COVID-19 epidemic? The Lancet. 2020;395(10228):931-4.

[67] Liu L, Li D, Ma Y, Shen H, Zhao S, Wang Y. Combined application of arbuscular mycorrhizal fungi and exogenous melatonin alleviates drought stress and improves plant growth in tobacco seedlings. Journal of Plant Growth Regulation. 2020:1-14.

[68] Xu S, Wang J, Shou W, Ngo T, Sadick A-M, Wang $\mathrm{X}$. Computer vision techniques in construction: a critical review. Archives of Computational Methods in Engineering. 2020:1-15.

[69] Lee J. Mental health effects of school closures during COVID-19. Lancet Child Adolesc Heal 4:421. Link: https:// bitly/31EMr0B. 2020.

[70] Wu C, Wu P, Wang J, Jiang R, Chen M, Wang X. Critical review of data-driven decision-making in bridge operation and maintenance. Structure and Infrastructure Engineering. 2020:1-24.

[71] Ka-Kay Pang R, Granados O, Chhajer H, Fille Legara E. An analysis of network filtering methods to sovereign bond yields during COVID-19. arXiv e-prints. 2020:arXiv: 2009.13390.

[72] Khan K, Zhao H, Zhang H, Yang H, Shah MH, Jahanger A. The impact of COVID-19 pandemic on stock markets: An empirical analysis of world major stock indices. The Journal of Asian Finance, Economics, and Business. 2020; 7(7):463-74.

[73] Yang W, Pudasainee D, Gupta R, Li W, Wang B, Sun L. An overview of inorganic particulate matter emission from coal/biomass/MSW combustion: Sampling and measurement, formation, distribution, inorganic composition and influencing factors. Fuel Processing Technology. 2020: 106657.

[74] Clarke A, Stephens A, Liao S, Byrne T, Gregory S. Coping with COVID-19: ventilator splitting with differential driving pressures using standard hospital equipment. Anaesthesia. 2020.

[75] Yan B, Stuart L, Tu A, Zhang T. Analysis of the Effect of COVID-19 on the Stock Market and Investing Strategies. Available at SSRN 3563380. 2020.

[76] Gössling S, Scott D, Hall CM. Pandemics, tourism and global change: a rapid assessment of COVID-19. Journal of Sustainable Tourism. 2020:1-20.

[77] Savvides SC. Debt liquidity and recession economics during the pandemic: a blessing or a curse? Available at SSRN 3642602. 2020.

[78] Wang Q, Xu R, Volkow ND. Increased risk of COVID19 infection and mortality in people with mental disorders: analysis from electronic health records in the United States. World Psychiatry. 2020.

[79] Matsuzawa Y, Ogawa H, Kimura K, Konishi M, Kirigaya J, Fukui K, et al. Renin-angiotensin system inhibitors and the severity of coronavirus disease 2019 in Kanagawa, Japan: a retrospective cohort study. Hypertension Research. 2020;43(11):1257-66.

[80] Grasselli G, Zangrillo A, Zanella A, Antonelli M, Cabrini L, Castelli A, et al. Baseline characteristics and outcomes of 1591 patients infected with SARS-CoV-2 admitted to ICUs of the Lombardy Region, Italy. Jama. 2020;323(16): 1574-81.

[81] Jia R, Ayling K, Chalder T, Massey A, Broadbent E, Coupland C, et al. Mental health in the U.K. during the COVID-19 pandemic: cross-sectional analyses from a community cohort study. BMJ Open. 2020;10(9): e040620.

[82] Savage MJ, James R, Magistro D, Donaldson J, Healy LC, Nevill M, et al. Mental health and movement behaviour during the COVID-19 pandemic in U.K. university students: Prospective cohort study. Mental Health and Physical Activity. 2020;19:100357.

[83] Alessi J, De Oliveira GB, Franco DW, Do Amaral BB, Becker AS, Knijnik CP, et al. Mental health in the era of COVID-19: prevalence of psychiatric disorders in a 
cohort of patients with type 1 and type 2 diabetes during the social distancing. Diabetology \& Metabolic Syndrome. 2020;12(1):1-10.

[84] Zheng KI, Gao F, Wang X-B, Sun Q-F, Pan K-H, Wang T-Y, et al. Obesity as a risk factor for greater severity of COVID19 in patients with metabolic associated fatty liver disease. Metabolism. 2020;108:154244.

[85] Iob E, Frank P, Steptoe A, Fancourt D. Levels of Severity of Depressive Symptoms Among At-Risk Groups in the UK During the COVID-19 Pandemic. JAMA Network Open. 2020;3(10):e2026064-e.

[86] Ettman CK, Abdalla SM, Cohen GH, Sampson L, Vivier PM, Galea S. Prevalence of depression symptoms in U.S. adults before and during the COVID-19 pandemic. JAMA Network Open. 2020;3(9):e2019686-e.

[87] Roy D, Tripathy S, Kar SK, Sharma N, Verma SK, Kaushal V. Study of knowledge, attitude, anxiety \& perceived mental healthcare need in Indian population during COVID-19 pandemic. Asian Journal of Psychiatry. 2020:102083.
[88] Zhang SX, Wang Y, Jahanshahi AA, Schmitt VGH. First study on mental distress in Brazil during the COVID-19 crisis. medRxiv. 2020.

[89] Karpenko OA, Syunyakov TS, Kulygina MA, Pavlichenko AV, Chetkina AS, Andrushchenko AV. Impact of COVID-19 pandemic on anxiety, depression and distress-online survey results amid the pandemic in Russia. Consortium Psychiatricum. 2020;1(1).

[90] Essadek A, Rabeyron T. Mental health of French students during the Covid-19 pandemic. Journal of Affective Disorders. 2020;277:392-3.

[91] Özdin S, Bayrak Özdin Ş. Levels and predictors of anxiety, depression and health anxiety during COVID-19 pandemic in Turkish society: The importance of gender. International Journal of Social Psychiatry. 2020:0020764020927051.

[92] Rossi R, Socci V, Talevi D, Mensi S, Niolu C, Pacitti F, et al. COVID-19 pandemic and lockdown measures impact on mental health among the general population in Italy. Frontiers in psychiatry. 2020;11:790. 